\title{
Mikrostrukturalne procesy degradacyjne normalizowanej stali zlewnej z mostu kolejowego
}

\author{
Microstructural degradation processes \\ normalized cast steel from railway bridge
}

\section{Streszczenie}

Nietypowe wyniki badań materiałowo-wytrzymałościowych stali mostu kolejowego, wybudowanego w roku 1938, pozwoliły ustalić, że został on wykonany ze stali zlewnej normalizowanej. Fakt ten potwierdziły wyniki badania mikrostrukturalnych, które określiły stopień zdegradowania stali gatunku St 37-12. Prawdopodobnie są to priorytetowe badania starzeniowe tego rodzaju stali.

Słowa kluczowe: most kolejowy, stal normalizowana, procesy starzeniowe

\begin{abstract}
Abnormal results of material-strength steel railway bridge, built in 1938, have established that it is made of stainless confluent normalized. This fact is confirmed by the results of the microstructural studies that have determined the degree of degradation of steel grade St $37-12$. Probably these are the priority aging tests of this type of steel.
\end{abstract}

Keywords: railway bridge, normalized steel, aging processes

\section{Wstęp}

Właściwości materiałowe i użytkowe stali intrygują projektantów i konstruktorów od początku jej stosowania w konstrukcjach nośnych. W odniesieniu do konstrukcji budowlanych zagadnienia te już w XIX wieku przedstawiano obszernie $\mathrm{m}$.in. w monografiach $[1 \div 3]$. Wiele $z$ omawianych tam obiektów zachowało się do dnia dzisiejszego i w większości są one w stanie bezpiecznie przenosić obciążenia użytkowe bez konieczności wzmocnienia. Uwaga ta dotyczy w szczególności kolejowych mostów stalowych.

Do chwili obecnej nie udało się opracować jednego uniwersalnego algorytmu do oceny nośności i stanu technicznego stalowych mostów użytkowanych przez dłuższy czas. Każdy przypadek należy rozpatrywać indywidualnie na podstawie

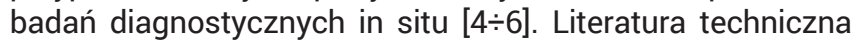
tłumaczy to faktem, że nie ma dwóch takich samych stali, nawet minimalne zmiany $w$ składzie chemicznym lub parametrach wytwarzania mogą drastycznie zmienić jej właściwości. Dotyczy to w szczególności obiektów wybudowanych w drugiej połowie XIX wieku i na początku wieku XX. Postęp w procesach metalurgicznych i rozwój różnych metod obróbki cieplnej umożliwił zmiany właściwości stali w dość szerokich granicach. Obok niskowęglowych stali zlewnych zaczęto stosować do konstrukcji budowlanych stale niskostopowe oraz wprowadzać zabiegi obróbki cieplnej $[7,8]$.

Taki przypadek mostu kolejowego wykonanego z nietypowego gatunku stali zlewnej opisany został w niniejszym referacie. Jest to most wybudowany przez Niemców w 1938 r. na obecnej linii kolejowej nr 367 Zbąszynek - Gorzów w km 73,303. Przed remontem mostu przeprowadzono rutynowe badania stali celem oszacowania parametrów wytrzymałościowych potrzebnych do projektu modernizacyjnego, które omówiono w [8]. Zadziwiające wartości uzyskano z badań udarności Charpy'ego, których wyniki przedstawiono graficznie na rys.1. Udarność określono z badań dwóch typów próbek pobranych z elementów konstrukcyjnych mostu:

- starzonych samorzutnie - S, czyli bez dodatkowych zabiegów obróbki cieplnej

- normalizowanych - N, czyli wyżarzonych w temperaturze $930{ }^{\circ} \mathrm{C}$ przez jedną godzinę i studzonych na powietrzu.

Próbki stali normalizowanej cechuje drobne ziarno i właściwości mechaniczne porównywalne z cechami stali z okresu budowy mostu.

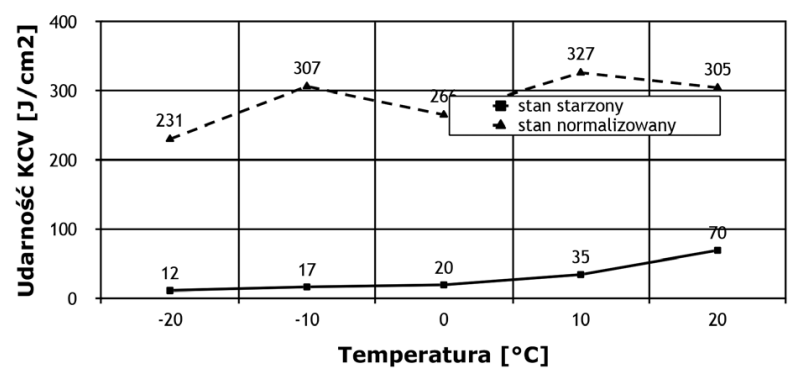

Rys. 1. Średnia udarność z 30 próbek stali starzonej i normalizowanej Fig. 1. The average impact strength of 30 samples of aged and normalized steel

Dr hab. inż. Bernard Wichtowski, prof. ZUT; dr hab. inż. Walenty Jasiński, prof. ZUT - Zachodniopomorski Uniwersytet Technologiczny w Szczecinie. 


\section{Rys konstrukcyjny mostu}

Stalowy most kolejowy przez rzekę Wartę usytuowany jest na jednotorowej linii kolejowej nr 367 Zbąszynek-Go-

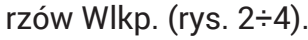

Most ma osiem przęseł o rozpiętościach: $26,00+31,82$ $+31,82+36,50+38,30+95,80+27,11+27,02=314,37 \mathrm{~m}$, a jego długość całkowita wynosi 315,57 m. Siedem przęseł to blachownicowe konstrukcje nitowane $z$ jazdą dołem oraz jedno przęsło kratownicowe (konstrukcja Langera). Historię mostu oraz wyniki badań wytrzymałościowych stali z jego konstrukcji przedstawiono w [8].

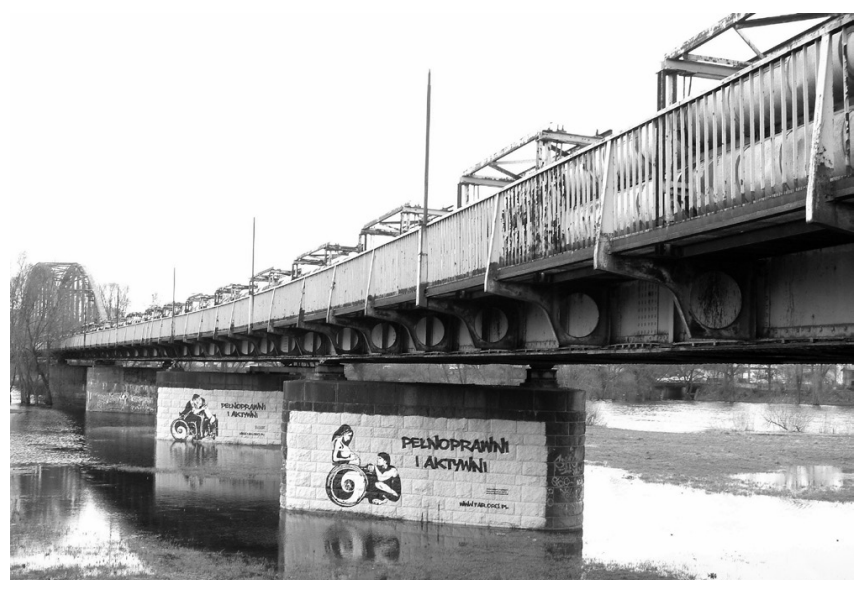

Rys. 2. Widok mostu na jednotorowej linii kolejowej nr 367 Zbąszynek-Gorzów

Fig. 2. View of the bridge on the single-track railway line 367 Zbąszynek-Gorzów

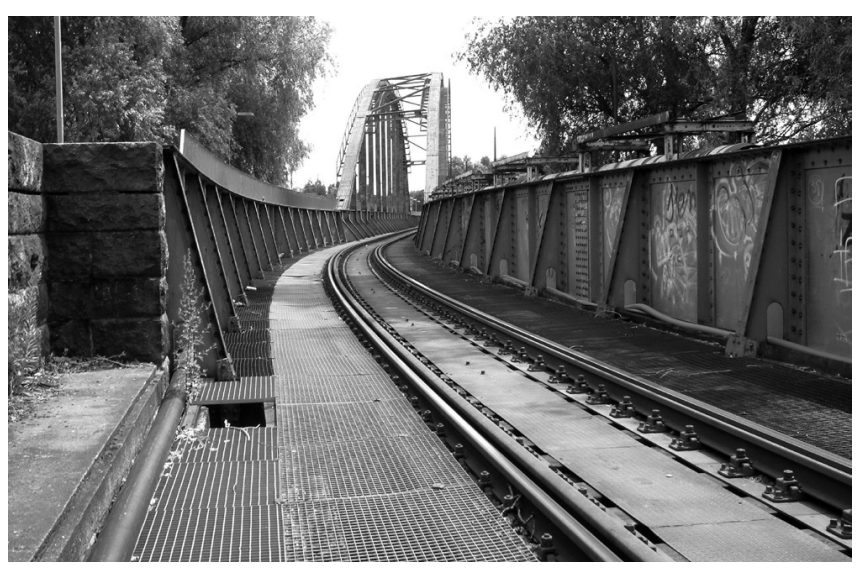

Rys. 3. Widok torowiska na moście przez Wartę na linii kolejowej Zbąszynek-Gorzów

Fig. 3. View of the tracks on the bridge over the Warta River on the line Zbąszynek-Gorzów

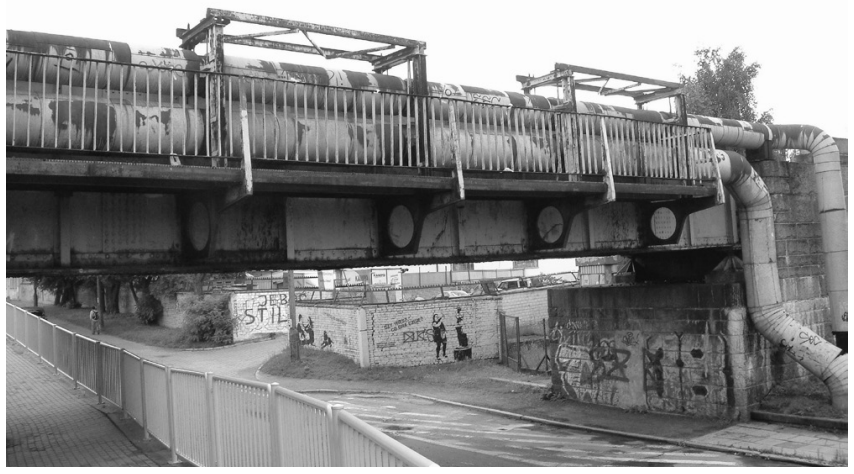

Rys. 4. Widok skrajnego dźwigara, z którego pobrano próbki do badań Fig. 4. The view of the extreme girder from which the samples for testing were used

\section{Badania mikrostrukturalne}

Zaskakująco duże jest zestarzenie stali mostu określone z udarności stali KCV podanej na rys. 1. Wskaźnik starzenia Ws, równy ilorazowi udarności próbek $\mathrm{S}$ do $\mathrm{N}$ w zakresie temperatur od $-20{ }^{\circ} \mathrm{C}$ do $20{ }^{\circ} \mathrm{C}$ wynosi : 0,$05 ; 0,06 ; 0,08 ; 0,11$ i 0,23 . Celem wyjaśnienia tego zjawiska przeprowadzono badania metalograficzne. Od dłuższego czasu Ośrodek Wrocławski postuluje wprowadzenie badań metalograficznych i udarnościowych do programu oceny stanu technicznego mostów [12:14]. Poza tym celem tych badań było określenie wielkości ziarna stali $w$ stanie poeksploatacyjnym $\mathrm{S}$ i w stanie normalizowanym - N, które pozwoli potwierdzić słuszność założenia, że stal mostu jest stalą normalizowaną gatunku St 37-12.

W celu ujawnienia obecności degradacyjnych zmian mikrostrukturalnych przeprowadzono obserwacje metalograficzne stali w stanach:

- poeksploatacyjnym, starzonym samorzutnie - S (rys. 5 i 6 )

- normalizowanym w temperaturze $930^{\circ} \mathrm{C}$ przez $0,5 \mathrm{~h}-\mathrm{N} 1$ (rys. 7)

- wyżarzania zupełnego $w$ temperaturze $930{ }^{\circ} \mathrm{C}$ przez $2 \mathrm{~h}$ i chłodzeniu z piecem - WZ (rys. 8)

- normalizowanym w temperaturze $930{ }^{\circ} \mathrm{C}$ przez $2 \mathrm{~h}-\mathrm{N} 2$ (rys. 9)

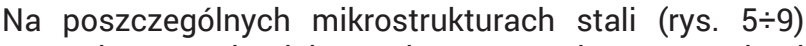
oznaczenie stopnia ich zanieczyszczenia wtrąceniami niemetalicznymi dokonano zgodnie $z$ wymaganiami normy PN-64/H-04510 [15]. Jednocześnie należy zaznaczyć, że powiększenia w opisie rysunków odpowiadają wydrukowi na formacie A4 gdzie rysunki maja rozmiar $8 \times 6 \mathrm{~cm}$. Przy innej wielkości wydruku powiększenie ustalić na podstawie wielkości odcinków wzorcowych zamieszczonych w prawym

Tablica I. Skład chemiczny i właściwości mechaniczne stali

Table I. Chemical composition and mechanical properties of steels

\begin{tabular}{|c|c|c|c|c|c|c|c|c|}
\hline \multirow{2}{*}{ Rodzaj stali } & \multicolumn{6}{|c|}{ Skład chemiczny, [\%] } & \multirow{2}{*}{$\begin{array}{l}\mathrm{ReH}^{3{ }^{3}} \\
\mathrm{MPa}\end{array}$} & \multirow{2}{*}{$\begin{array}{l}\mathrm{R}_{\mathrm{m}}{ }^{3)} \\
\mathrm{MPa}\end{array}$} \\
\hline & C & $\mathrm{Mn}$ & SI & $\mathrm{P}$ & S & $P+S$ & & \\
\hline $\begin{array}{c}\text { most środnik } \\
(18 \mathrm{~mm})\end{array}$ & 0,034 & 0,460 & 0,045 & 0,006 & 0,026 & 0,032 & $\begin{array}{c}220 \\
(275)\end{array}$ & $\begin{array}{c}342 \\
(376)\end{array}$ \\
\hline $\begin{array}{l}\text { St } 37 \text { - } 12 \\
\text { Thomas }^{1)}\end{array}$ & $\begin{array}{l}\max \\
0,16 \\
\end{array}$ & $0,40 \div 0,50$ & $\sim 0,01$ & $\begin{array}{l}\max \\
0,09\end{array}$ & $\begin{array}{l}\max \\
0,06\end{array}$ & $\begin{array}{c}\max \\
0,13\end{array}$ & \multirow{2}{*}{$\begin{array}{l}\min \\
230\end{array}$} & \multirow{2}{*}{$370 \div 450$} \\
\hline $\begin{array}{c}\text { St } 37-12 \\
\mathrm{Sm}^{2)}\end{array}$ & $\begin{array}{l}\max \\
0,20\end{array}$ & $0,40 \div 0,50$ & $\sim 0,01$ & $\begin{array}{l}\max \\
0,06\end{array}$ & $\begin{array}{l}\max \\
0,06\end{array}$ & $\begin{array}{l}\max \\
0,10\end{array}$ & & \\
\hline
\end{tabular}

1) produkcja w konwertorach Thomasa, 2) produkcja w piecach Simens-Martin, 3) bez nawiasów próbki starzone, w nawiasach próbki normalizowane 
dolnym rogu rysunku. Na rysunkach o zaznaczonym w podpisie powiększeniu x70 długość odcinka pomiarowego wynosi $100 \mu \mathrm{m}$, a na rysunkach x350 odpowiednio $50 \mu \mathrm{m}$.

Obserwacje zgładów wzdłużnych nietrawionych próbek w stanie poeksploatacyjnym - S, ujawniły obecność wtrąceń niemetalicznych o zróżnicowanym stopniu nasilenia. Obok obszarów o stopniu nasilenia tlenków punktowych TP1 - rysunek 5a, występują obszary o stopniu nasienia tlenków punktowych TP2, tlenków łańcuszkowych TŁa1 i krzemianów plastycznych KPa1 (rys. 5b). Dominują obszary o pośrednim stopniu nasilenia wtrąceń niemetalicznych.

W stanie poeksploatacyjnym - S mikrostrukturę stanowi osnowa ferrytyczna z niewielką ilością perlitu oraz wtrące- niami tlenków i krzemianów - rysunek 6. Przy powiększeniu 350x na granicach ziarn ferrytu widoczne są wydzielenia cementytu trzeciorzędowego $\left(\mathrm{Fe}_{3} \mathrm{C}\right)$ o stopniu nasilenia odpowiadającym wzorcowi 2/B1 - rysunek $6 \mathrm{~b}$. Nie stwierdzono obecności mikrostruktury Widmannstättena.

W celu usunięcia skutków starzenia eksploatacyjnego przeprowadzono zabieg wyżarzania normalizacyjnego $w$ temperaturze $930^{\circ} \mathrm{C}$ w czasie $0,5 \mathrm{~h}$. W wyniku przekrystalizowania mikrostruktury nastąpiło rozdrobnienie ziarna ale w dalszym ciągu pozostały na granicach ziarn nierozpuszczone wydzielenia cementytu trzeciorzędowego (rys. 7).

W celu ograniczenia ilości nierozpuszczonych wydzieleń cementytu trzeciorzędowego przeprowadzono wyżarzanie
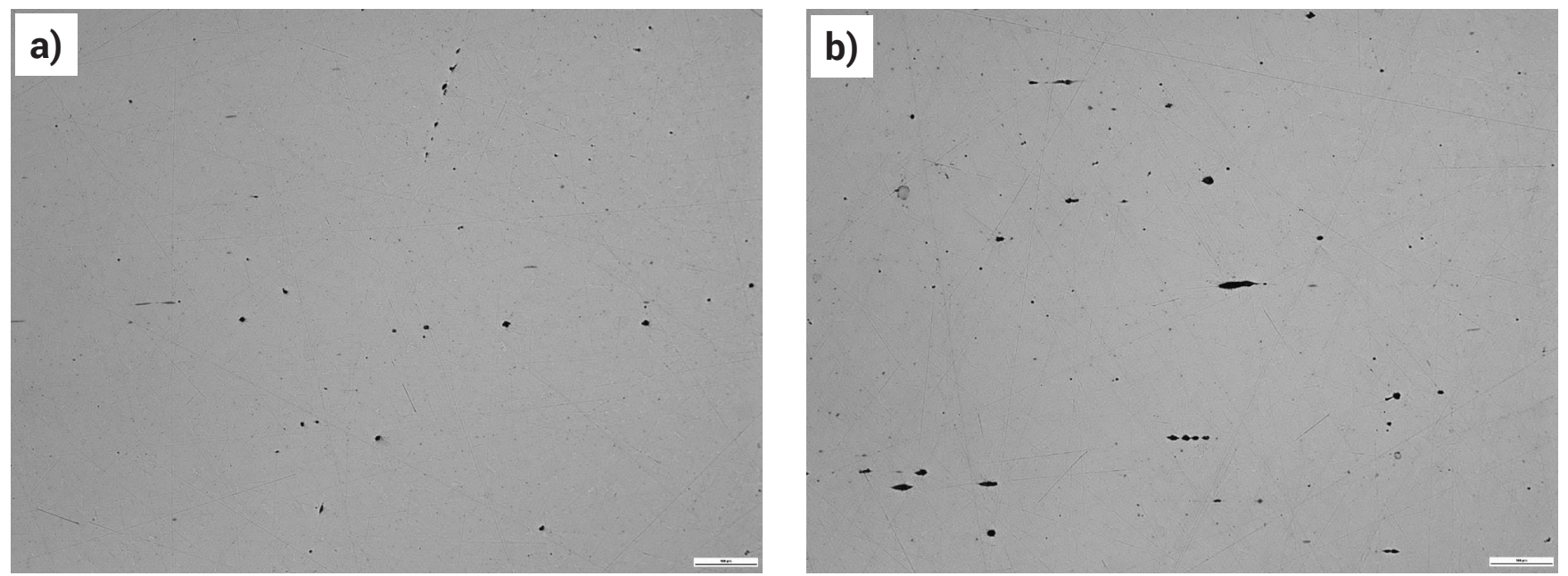

Rys. 5. Zgład nietrawiony próbek - S, x70: a) obszar TP1, b) obszar TP2, TŁa1, KPa1

Fig. 5. Metallographic section undigested samples $-S, x 70$ : a) the area TP1, b) the area TP2, TŁa1, KPa1
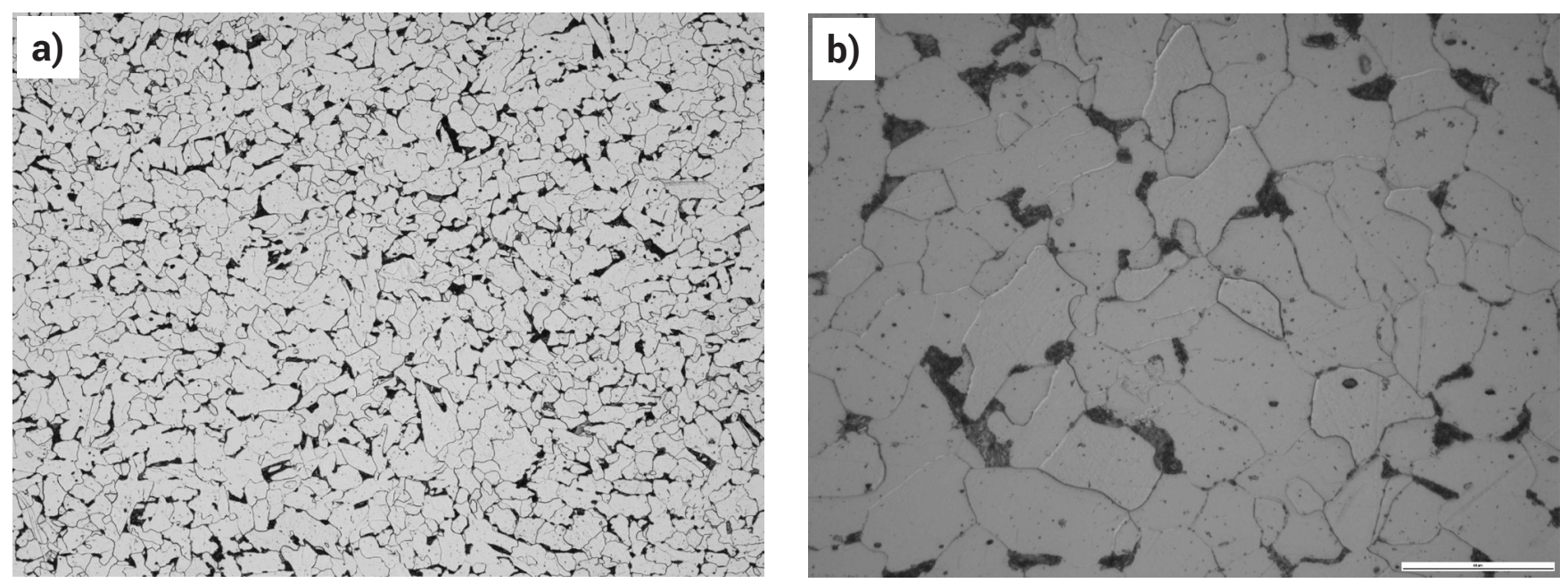

Rys. 6. Mikrostruktura próbek starzonych - S: a) x70, b) x350

Fig. 6. The microstructure of the aged samples: a) $\times 70, b) \times 350$
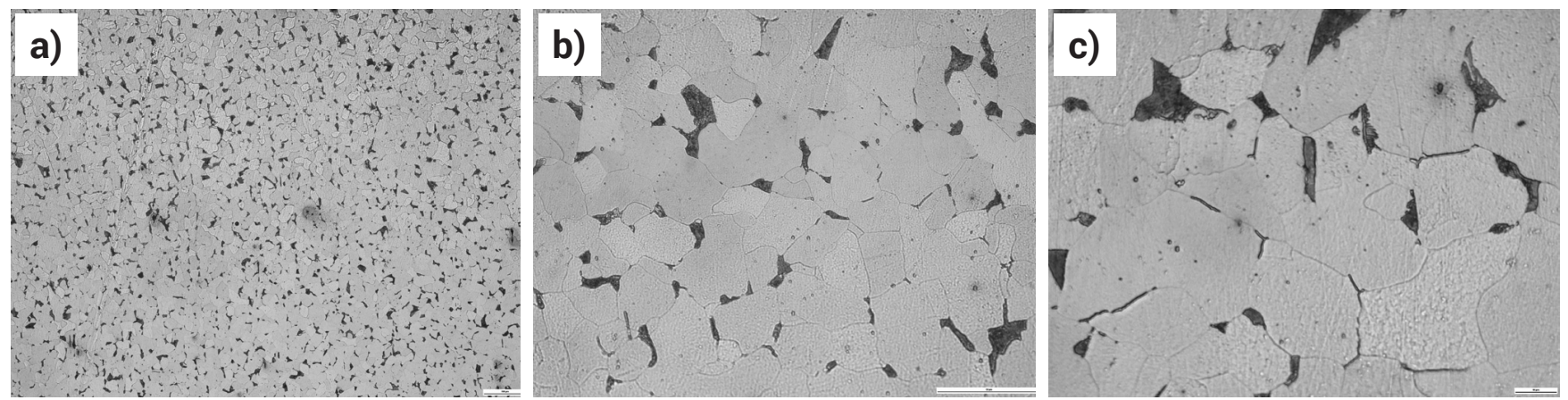

Rys. 7. Mikrostruktura w stanie normalizowanym - N1: a) x70, b) x350, c) $x 700$

Fig. 7. The microstructure in the normalized state $-\mathrm{N} 1$ : a) $\times 70$, b) $\times 350$, c) $\times 700$ 
zupełne - WZ i normalizujące - N2 w temperaturze $930^{\circ} \mathrm{C} / 2 \mathrm{~h}$ $\mathrm{z}$ chłodzeniem po austenityzowaniu odpowiednio $\mathrm{w}$ piecu i na powietrzu. (rys. 8 i 9). Po procesie wyżarzania zupełnego - WZ w mniejszym nasileniu, widoczne są wydzielenia cementytu trzeciorzędowego na granicach ziarn ferrytu oraz powiększają się wydzielenia wewnątrz ziarn ferrytu (rys. 8c).
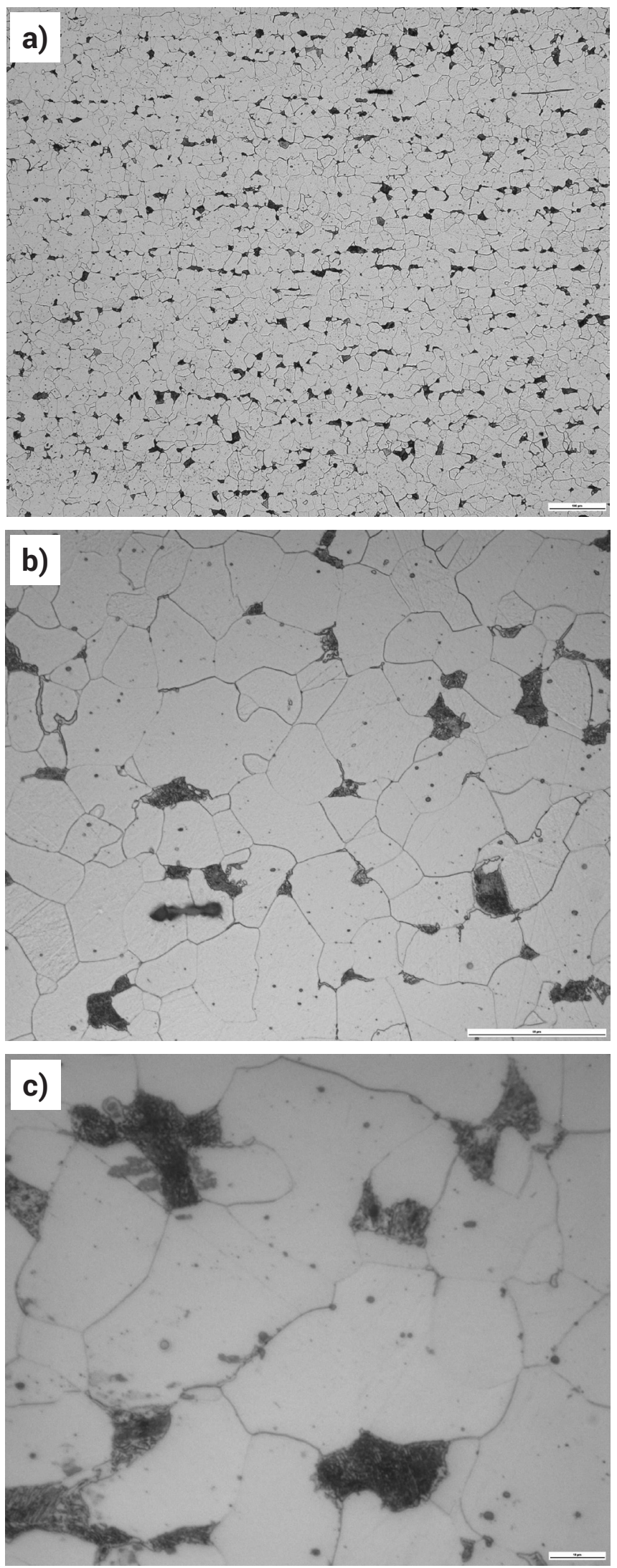

Rys. 8. Mikrostruktura w stanie wyżarzonym zupełnie - WZ: a) x70, b) $x 350$, c) $x 700$

Fig. 8. The microstructure in the annealed state - WZ: a) $x 70$, b) $\times 350$, c) $\times 700$
Mikrostrukturę o większej dyspersji i równoosiowym ziarnie uzyskano po procesie normalizowania $930{ }^{\circ} \mathrm{C} / 2 \mathrm{~h}-\mathrm{N} 2$ (rys. 9). Podobnie jak po wyżarzaniu zupełnym -WZ obserwuje się pozostałości cementytu trzeciorzędowego na granicach ziarn ferrytu przy mniejszym udziale wydzieleń wewnątrz ziarn ferrytu.
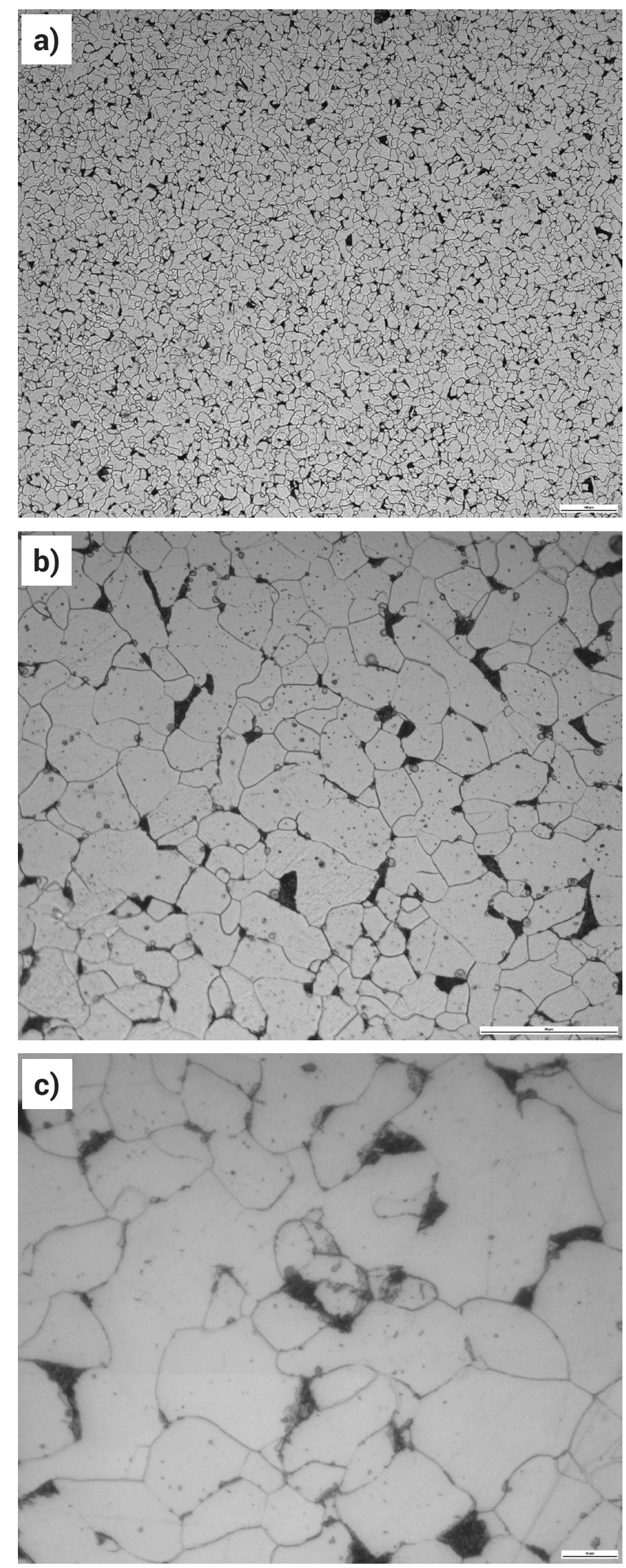

Rys. 9. Mikrostruktura w stanie normalizowanym - N2 : a) x70, b) $x 350$, c) x700

Fig. 9. The microstructure in the normalized state - N2: a) $x 70$, b) $\times 350$, c) $\times 700$ 


\section{Określenie wielkości ziarna}

Określenia wielkości ziarna przeprowadzono metodą porównawczą (wg skali wzorców) zgodnie z wymaganiami PN-EN ISO 634:2005 [16]. Podobnie jak przy obserwacjach metalograficznych stali i tutaj określenie wielkości ziarna przeprowadzono dla próbek stali w stanach:

- poeksploatacyjnym, starzonym samorzutnie - S (rys. 10),

- wyżarzonym zupełnie $w$ temperaturze $930{ }^{\circ} \mathrm{C}$ przez $2 \mathrm{~h}$ i studzeniu razem z piecem - WZ (rys.11),

- wyżarzonym normalizująco w temperaturze $930^{\circ} \mathrm{C}$ przez $2 \mathrm{~h}$ i chłodzeniu na powietrzu - N2 (rys.12),

Wielkość ziarna w stanie starzonym - S odpowiada wzorcowi G5 o średniej średnicy ziarna dm =0,0625 mm - (rys. 10).

W stanie wyżarzonym zupełnie - WZ wielkość ziarna uległa zmniejszeniu i odpowiada wzorcowi G6 o średniej średnicy ziarna $\mathrm{d}_{\mathrm{m}}=0,0442 \mathrm{~mm}-$ (rys. 11).

W stanie wyżarzonym normalizująco - N2 wielkość ziarna uległa zmniejszeniu i odpowiada wzorcowi G7 o średniej średnicy ziarna $\mathrm{d}_{\mathrm{m}}=0,0312 \mathrm{~mm}-$ (rys. 12).

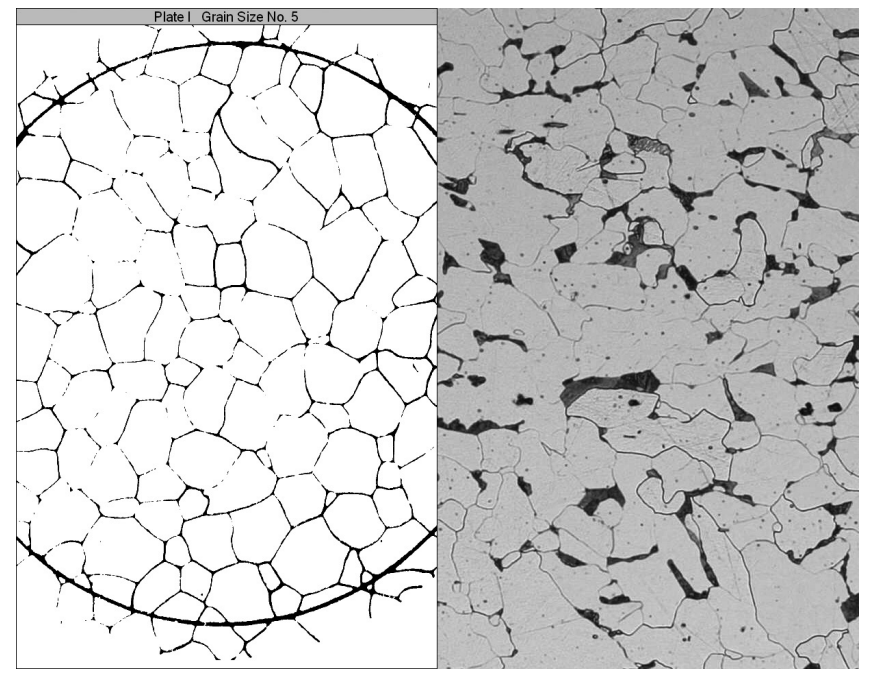

Rys. 10. Wielkość ziarna w stanie starzonym - S

Fig. 10. The grain size in the aged state $-S$

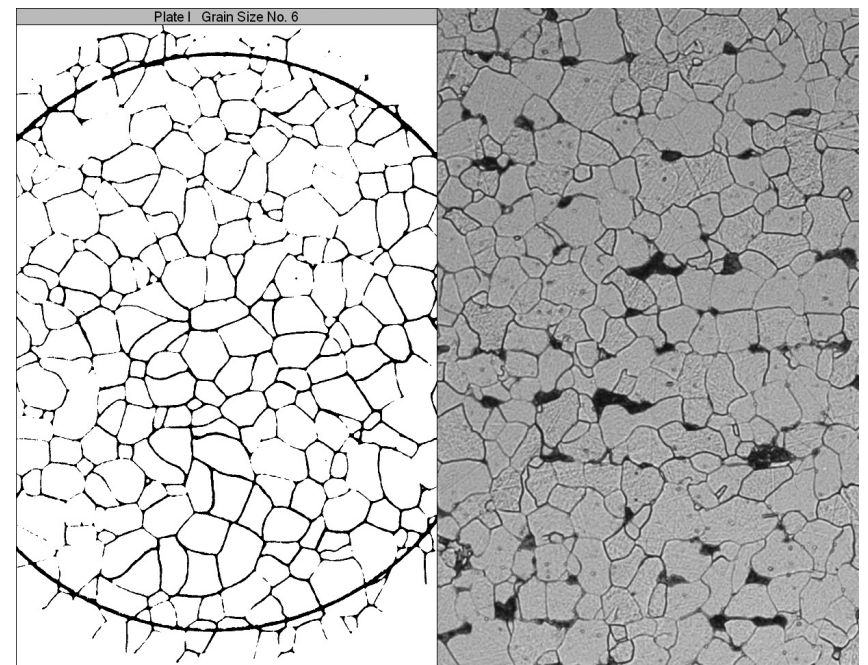

Rys. 11. Wielkość ziarna w stanie wyżarzonym zupełnie - WZ Fig. 11. The microstructure in the annealed state $-W Z$

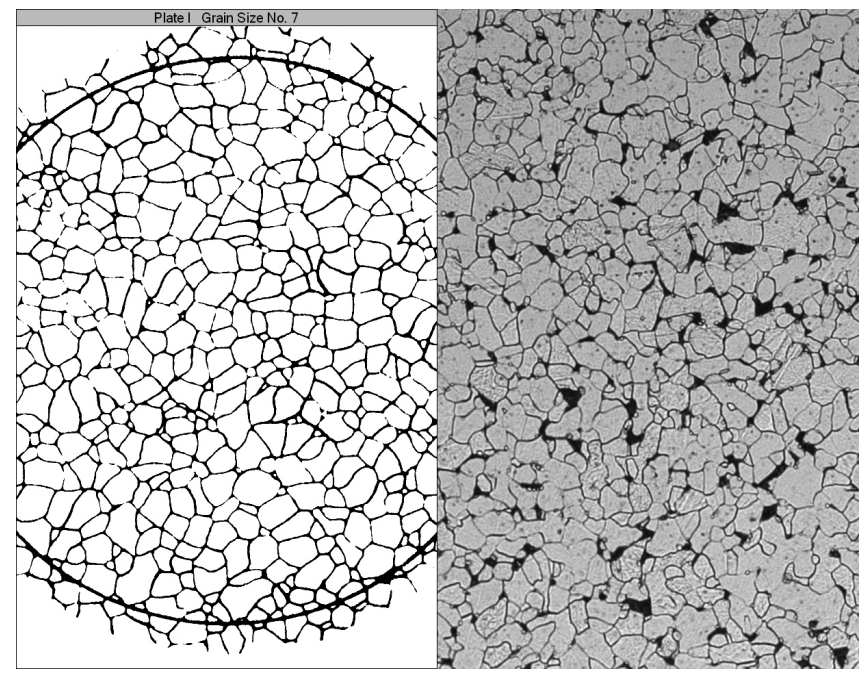

Rys. 12. Wielkość ziarna w stanie wyżarzonym normalizująco - N2 Fig. 12. The microstructure in the normalized state $-\mathrm{N} 2$

\section{Podsumowanie}

Analizowana w referacie stal mostu kolejowego, oddanego do eksploatacji w 1938 roku, to stal zlewna gatunku St 37-12. Jest to stal drobnoziarnista o aktualnym numerze wielkości ziarna G5, czyli o średniej średnicy ziarna $\mathrm{dm}=0,0625 \mathrm{~m}$. Aktualna wartość jej granicy plastyczności ReH= $220 \mathrm{MPa}$, a granica wytrzymałości $\mathrm{Rm}=340 \mathrm{MPa}$. Wartosci te są jedynie o 4,3 i 8,1 \% mniejsze od minimalnych wartości zalecanych przez norme DIN 1612 dla tego gatunku stali. Według [11], w latach 1894-1897, ze stali tej wybudowano most pod Müngsten, w którym łuk o rozpiętości 170 m miał wysokość 107 metrów.

W świetle powyższych danych, jak wytłumaczyć fakt opatentowania w roku 1930 [17]: „sposobu wytwarzania stali ze zmniejszoną skłonnością do powstawania złomu wskutek kruchości" ? Wynalazek polegał na poddaniu stali mechanicznej obróbce na zimno, a następnie "żarzeniu w temperaturze $700^{\circ}-950^{\circ}$."

Przedstawione wyniki badań materiałowych stali zlewnej St 37-12, starzonej przez 75 lat wykazały, że zmiany degradacyjne polegały na:

- zwiększonym wydzielaniu cementytu trzeciorzędowego $\left(\mathrm{Fe}_{3} \mathrm{C}\right)$ na granicach ziarn ferrytu przy mniejszym udziale wydzieleń wewnątrz samych ziarn,

- zmiany degradacyjne znalazły odzwierciedlenie w badaniach udarnościowych (rys. 1), a ich udział w kontekście oce-

ny bezpieczeństwa i oszacowania trwałości obiektu jest niemożliwy do określenia.

Według autorów referatu przydatność użytkowa badania procesów degradacyjnych stali mostowej jest dyskusyjna w szczególności prowadzonych jednocześnie badaniach udarnościowych.

Omówione badania starzonej stali normalizowanej to prawdopodobnie priorytetowe badania tego gatunku stali. Autorzy uważają, że są to „badania przyszłościowe”, gdyż według Eurokodu 3 obecnie w konstrukcjach mostowych należy stosować stal gatunku co najmniej S355 w stanie normalizowanym (N, NL) bądź po walcowaniu termomechanicznym (M, ML) [18]. Istnieje prawdopodobieństwo wystąpienia w tych stalach analogicznej degradacji materiałowej jak w analizowanej stali St 37-12. 


\section{Literatura}

[1] Holley A.L.: The Use of Steel for Constructive Purpose; metod of working, applying and testing plates and bars. D. van Nostrand, Publisher, New York 1875.

[2] Waddell J.A.L.: General Specifications for Highway Bridges of Iron and Steel. Selden G. Spencer, Kansas City 1889.

[3] Cambell H.H.: The Manufacture and Propertis of structural steel. The Scientific Publishing Co., New York and London 1896.

[4] Hołowaty J., Wichtowski B.: Properties of structural Steel Used in Earlier Railway Bridges. Structural Engineering International, 4/2013.

[5] Wichtowski B., Hołowaty J.: Analiza właściwości materiałowych i spawalności stali zlewnej mostów kolejowych. Inżynieria i Budownictwo, nr 5/2013.

[6] Hołowaty J., Wichtowski B.: O stanie technicznym najstarszego w Polsce wiaduktu drogowego ze stali zlewnej. Inżynieria i Budownictwo, nr 7-8/2013.

[7] Hołowaty J., Wichtowski B.: Badania stali dwóch mostów kratownicowych na linii kolejowej nr 273. XXYII. Konferencja "Awarie budowlane", Międzyzdroje 2015.

[8] Wichtowski B., Woźniak Z.: Właściwości normalizowanej stali zlewnej mostu kolejowego po 75 latach eksploatacji. (Referat zgłoszony na XXI N-T Krajową Konferencję Spawalniczą, Międzyzdroje 2015).

[9] DIN 1612: 1932-01 Flußstahl gewalzt - Formstahl, Stabstahl, Breitflachstahl (Alte Bezeichnung, Formeisen, Stabeisen, Univesaleisen).

[10] Stahl in Hochbau. Taschenbuch fur Entwurf, Berechnung und Ausfuhrung von Stahlbauten. Verlag von Stahleisen m.b.H. Düsseldorf,1935.

[11] SchaperG.: Stälerne Brücken. Verlag von Wilhelm Ernst\&Sohn, Berlin, 1949.

[12] Ambroziak A., Pękalski G., Rabiega J.: Propozycje metod oceny stanu degradacji stalowych konstrukcji mostowych z przełomu XIX i XX wieku. Wrocławskie Dni Mostowe, Wrocław 2008.

[13] Lesiuk G., Szata M.: Wpływ procesów mikrostruktur na udarność stali zgrzewanych, Logistyka nr 6/2010.

[14] Lesiuk G. Rabiega J., Szata M.; Mikrostrukturalne procesy degradacyjne zachodzące w XIX-wiecznych stalach zgrzewanych. Inżynieria i Budownictwo, nr 11/2013.

[15] PN-64/H-04510 - Oznaczanie stopnia stali wtrąceniami niemetalicznymi.

[16] PN-EN ISO 634: 2005 - Stal. Mikrograficzne określenie wielkości ziarna.

[17] Urząd Patentowy Rzeczypospolitej Polskiej. Opis patentowy $\mathrm{Nr} 11489$ z 15 marca $1930 \mathrm{r}$.

[18] Wichtowski B.: Wymagania materiałowo-spawalnicze w mostach stalowych według zaleceń PN-EN 1993-2. Inżynieria i Budownictwo, nr 11/2013. 